\title{
Wildlife Resources of Ethiopia: Opportunities, Challenges and Future Directions: From Ecotourism Perspective: A Review Paper
}

\author{
Alemneh Amare \\ Department of Natural Resource Management, Wolkite University, Wolkite, Ethiopia \\ Email: alemneh.amare@wku.edu.et \\ Received 15 April 2015; accepted 22 June 2015; published 26 June 2015 \\ Copyright (C) 2015 by author and Scientific Research Publishing Inc. \\ This work is licensed under the Creative Commons Attribution International License (CC BY). \\ http://creativecommons.org/licenses/by/4.0/ \\ (c) (i) Open Access
}

\begin{abstract}
The economy of Ethiopia has prospered for many years on agricultural products but currently, the country expands to industrialization and service providing for additional incomes. However, the wildlife tourism and conservation practices are still at low attention. Therefore, this review paper identifies potential opportunities and wildlife diversity to promote wildlife tourism practices in Ethiopia. Furthermore, it also identifies the challenges and future directions to put into practice for future wildlife tourism industry. Wildlife tourism is one of the best potential economies to the country due to the presence of magnificent diversity of wildlife with high endemism and expansion of protected areas. The main intentions of tourists are to visit large mammals and birds with their natural habitats. The country earns million dollars per year only from protected areas through nature based tourism. The Montane and Afroalpine, Rift Valley and Transboundary ecosystem, a world class icon for wildlife tourism which attracts various tourists, and potential tourism destination for Ethiopia due to its high mammalian diversity and scenic area. The expansion of protected areas, peaceful and friendly people, and endemism promote tourism industry in Ethiopia. Even though, Ethiopia is the third country next to Tanzania and Uganda in terms of land surface of protected area; human-wildlife conflict, loss of biodiversity, and limited tourism and conservation attention with poor infrastructure are some of the major challenges. To scale up wildlife tourism industry, better promotion with practical conservation practices, community based tourism approaches and infrastructures should be implemented throughout the whole area of tourist destination.
\end{abstract}

\section{Keywords}

Challenges, Ethiopia, Protected Areas, Tourism, Wildlife 


\section{Introduction}

The interaction between human being and nature was started before million years ago when human being was created. Their relationships have been increased and more intense during the hunt and gathering. Traditionally, many people perceived wildlife as only to some game species (almost exclusively birds, mammals, and fish) that has been hunted. Currently, the term "Wildlife" includes all living organisms that are not domesticated and found in the wild, even those that are not used for sport hunting (non-game species) [1]. In the recent past, before the expansion of wildlife promotion and education, some people also defined "wildlife" is only large mammals; such as elephants, lions, cheetah, hyena, leopard, buffalo and other related species. However, therefore, wildlife refers to the variety of all living organisms inhabiting in the wild, at the genetic, species and ecosystem levels on earth.

Tourism is an important strategy for socio-economic development in developing countries [2]. Wildlife is an important economic asset to many sub-Saharan Africa. Tourist hunting (or trophy or recreational hunting) is an important sub-sector of the overall tourism market, and one that is even more directly tied to particular species of large mammals [3]. Wildlife tourism is becoming the most common leisure, which increased major concerns because of its impression towards wild species and their habitats [1]. This popular industry, wildlife tourism, influences directly or indirectly the country's income through the involvement of wildlife-dependent or wildlifedependent recreation. Wildlife-independent recreation includes sighting or hearing the wild species within their natural habitats. On the other scenario, wildlife-dependent leisure is more disruptive though outside activities are usually intentional since visitor's satisfaction relies on the presence of wild species. It can be also extended activities ranges from leisure tracking of wildlife, to photographing and videotaping, and to sport or trophy hunting, mountaineering, game viewing to bird-watching (avitourism) in their habitats [1] [4].

Wildlife tourism can be recognized in many African countries, including Ethiopia: Safari tourism, ecotourism and recreational tourism. The Safari tourism is the most common excursion of national parks; it includes to a large public that is interested in viewing large mammals and colorful birds in a wild with exotic landscape and a range of nature tourism products. Many of these wildlife visitors will also be interested for integrated cultural and natural heritages [3] [5]. The ecotourism includes journeys for bird viewing, sport fishermen, speleologists (those who enjoy exploring caves and their wildlife), botanists and other ecologists, who interested on wildlife perspectives. Recreational tourism is residents and citizens who pursue the joys of the countryside at special occasions. However, this paper includes all these three tourism aspects.

Wildlife tourism is one of the key economic activities for countries that have rich biodiversity and high endemism. Nature based tourism includes a wide range of activities, such as bird-watching, whale-watching, general wildlife viewing, visiting zoos and aquaria, snorkeling to view underwater life, hunting and recreational fishing [1]. Wildlife tourism can also be categorized as either consumptive or non-consumptive, which based on the recreational intentions of tourists and the level of visitor-wildlife interactions.

In the previous decades, before the existence of mass tourism, visitors were content with viewing displayed animals in zoological gardens. These days, many tourists desire to get and interact with wild species in their habitats and experience a much more close to realistic habitats [1] [6]. The main attention of many tourists that visit Africa is to visit large mammals in great variety, large numbers and at close proximity [3] [7]. For example, large numbers of tourists, both local and foreign, watch sea turtles and whales in Australia like in some other parts of the world [8]. Proximity to animals particularly endemic large animals are an enormously best mechanism whereby tourists can excite by them with nature. The chance of human being connected with nature arguably difficult due to increment of urbanization and many people travel to "reconnect" with things natural to appreciate nature [7]-[9].

The main objective of this paper is to provide a review of the wildlife resources and historical development of wildlife tourism in Ethiopia, with particular reference to the opportunities and challenges that the industry faces in order to provide future direction for sustainable tourism development to the country.

\section{Historical Tourism Development in Ethiopia}

Many developing countries incorporated tourism as one of the main components of their economic development and foreign exchange earners. Gross income is more than $20 \%$ of the total value of merchandise exports are the most important export of goods and services. Ethiopia has a long history of conservation. The first recorded indigenous conservation-oriented activity took place during the reign of Emperor Zerea Yacob (1434-1468) [10]. 
It expanded after the victory of Italia at the battle of Adwa from the north corner of the country. Later, in the early $19^{\text {th }}$ century the wildlife conservation was only for large and flagship animals. For example, Emperor Menelik II on 1908 amended the first regulation, against young elephant hunting by peoples. Then, in 1960's based on the United Nations Scientific, Educational and Cultural Organization (UNESCO) suggestion to the country, Ethiopian Wildlife Conservation Organization (EWCO) was established in 1964 under Ministry of Agriculture. During this time two protected areas namely; Awash National Park and Simien Mountains National Park were established (Figure 2). The former EWCO changed its name to Ethiopian Wildlife Conservation Authority (EWCA) and formally re-established since 2008 under Ministry of Culture and Tourism aimed to manage and conserve the protected areas of the country.

The country's geology, archeological sites and landscape as well as cultural diversity have been contributed for tourism development and promotion. However, the wildlife tourism solely dependent on protected areas, primarily national parks and sanctuaries of the country. During the 1970s, trophy hunting was also conducted on a large scale in Ethiopia, though since then, increasing human populations, political instability and encroachment on wildlife habitat have resulted in a 95\% decrease in the area used for trophy hunting. The Mountain Nyala (Tragelaphus buxtoni) the species most commonly used by operators to attract visiting hunters to Ethiopia. Later, the government knew the importance of wildlife resources (primarily for large animals and scenic places) for tourism development due to revenue and supports the countries income. Therefore, the government has attached due attention to formulate a wildlife development and protection strategy in harmony with the country's goal, and the existing international natural resources development and protection principles [11]. Besides, the intention is to halt the decline of wild animal populations and enable the country to realize the maximum benefit from the sub-sector (in the form of tourism, live animals and products trade and hunting).

\section{Potential Opportunities}

\subsection{The Presence of Diversified Wildlife}

Ethiopia is located at $3^{\circ} 30^{\prime} \mathrm{N}$ and $15^{\circ} 00^{\prime} \mathrm{N}$ latitude and $33^{\circ} \mathrm{E}$ and $48^{\circ} \mathrm{E}$ longitudes in the horn of Africa, and one of the wildlife biodiversity centers of the world [12]-[14]. Ethiopia is one of the top 25 biodiversity-rich countries in the world, and hosts two of the world's 34 biodiversity hotspots, namely: the Eastern Afromontane and the Horn of Africa hotspots [11] [15].

The biogeographic of the country characterized by two features; namely the arid horn of Africa (Ogaden) and mosaic highland plateau [10] and results extremely rich and distinctive flora and fauna. This wildlife diversity is a great attraction of tourists; nature based tourism to support the country's economy and for future protected area management to the country [16] [17]. The country has a diverse and contrasting from the desert of the Dankil Depression, the lowest dry land points on earth at $116 \mathrm{~m}$ below sea level to Ras Dashen Mountain (the second peak and roof of Africa) at $4543 \mathrm{~m}$ above sea level [16]-[18]. The country has more than 1.3 million hectares (of which 1.12 million are land) with variety of climate, topography and vegetation supports high endemic flora and fauna of the country that attracts regional and global tourists [10] [18] (Table 1).

\subsubsection{Faunal Diversity}

Unlike the flora of Ethiopia, the fauna is not well investigated and documented. However, I tried to compile documents obtained from different literature to show the mammalian diversity that could contribute for tourism information and conservation development strategies (see Table 1).

Currently, around 320 species of mammal including 39 endemics (both small and large mammals), 918 birds with 19 endemic species, 240 reptiles (16 endemics), 71 amphibians (30 endemics) and 172 freshwater fishes with 38 endemics and more than 1225 insects recorded in Ethiopia (Table 1) [4]. Therefore, Ethiopia has one of the most diverse mammalian faunas in Africa and the great attractions of its wildlife heritage. Traditionally, many people simply represented Ethiopia as "Home of the Unique Seven" which refers to seven distinctive and large endemic mammals found only in Ethiopia. Those seven large mammals are; the Ethiopian wolf (Canis simensis), Mountainnyala (Tragelaphus buxtoni), Walia ibex (Capra walle), Menelik’s bush buck, Swayne's hartebeest (Alcelaphus buselaphus swaynei), Gelada baboon (Theropithecus gelada) and Bale monkey (Chlorocebus djamdjamensis) and the rest (83.9\%) are smaller ones including 2, 9 and 15 species of bats, insectivores and rodents, respectively. However, the country has more than seven large mammals [19]-[23]. For example, Boutourlini's blue monkey (Cercopithecus mitis boutourlini) which is an endemic sub species of blue monkey [24] 
Table 1. Wildlife (fauna/flora) resources of Ethiopia.

\begin{tabular}{cccc}
\hline Main Category & Sub Category & \# of Species & \# of Endemic Species \\
\hline & Mammal & 320 & 39 \\
Vertebrates & Birds & 918 & 19 \\
& Reptiles & 240 & 16 \\
& Amphibians & 71 & 30 \\
Invertebrates & Fish & 172 & 7 (Butterflies) \\
Vascular Plants & Insects & Arthropod 1225 & 625 \\
\hline
\end{tabular}

Source: [10] [17].

[25], Ethiopian Lion (Panthera leo abyssincum) [26], Starck’s Hare (Lepus starcki) and Giant mole rat (Tachyoryctes macrocephalus) were some of endemic mammals of Ethiopia that are not included under unique endemic species. The large mammals are mainly concentrated in the south and southwest border and adjacent area of the country. Furthermore, the Great Rift Valley and mountain massifs are also homes for many endemic mammals.

\subsubsection{Floral Diversity}

The floral part of Ethiopia varies from montane forests with coniferous and broadleaved forests, vast savannah, steppes and to deserts are interrupted by lakes with acacia commiphora woodland ecosystem, crossed by rivers and streams accompanied by galley forests [27]. The flora and topography also provides another excitement for tourists. However, I concentrated mainly on large mammals, due to tourist's intention with their habitats, and scenic places across three eco-regions on the protected area. Ethiopia has diverse floral diversity, more than 6500 species of vascular plants (with 625 endemic species and 669 near-endemic species, and one endemic plant genus) and ranked the fifth largest floral country in tropical Africa [10]. I excluded the non-vascular plants of Ethiopia due to limited studies and documentation.

\subsection{Expansion of Protected Area; Potential for Tourist Destination}

Protected areas are the main focus for the maintenance of biological diversity and contribute for economic developments of a nation. In the past few decades, the numbers of protected areas in developing countries are expanding [26]. The forest cover of Ethiopia declined from $47 \%$ to only $3 \%$ for the past few decades due to ever increasing population and anthropogenic effect [4]. Ethiopia had 40 protected areas covers about $16.4 \%$ of the country's land area [18] [28], and currently have more than $17.1 \%$ of its land, ranked third in African country next to Tanzania and Uganda Ethiopia (Figure 1). This crisis seems under recovering slowly in the future. The country is one of few countries where the establishments of protected areas are increasing. For example, Ethiopia had only two protected areas (namely; Awash and Simien Mountains National Park) before 40 years and today has more than 55 protected areas (including 21 national parks) [19] (Figure 2) to protect and conserve the natural ecosystems and wildlife heritage of the country [10] [29] (Table 2). Conversely, those protected areas are exposed to severe pressure, which threatens their existence and sustainability due to anthropogenic effects [19] [30]-[32]. The geographical distribution of protected areas of Ethiopia presented on (Figure 2).

\subsection{Wildlife Resources across Eco-Regions}

The incredible biogeography of Ethiopia is characterized by four distinct regions, namely; the Highlands, Rift Valley, Western Lowlands, and the Eastern Arid Areas of the country [16] (Figure 3). Even though, enormous and diverse potentials for wildlife tourism development in Ethiopia, the tourism is spatially limited to few national parks and sanctuaries. Based on the information obtained from tourist guiders and expertise, the paper focused on three major eco-regions for wildlife tourism attractions; 1 ) The unique Montane and Afroalpine ecosystem; 2) the Great Rift Valley; and 3) the Transboundary Migratory Ecosystem in the neighborhood of Gambella (Table 3).

\subsubsection{Montane and Afroalpine Protected Areas}

The extensive highlands of Ethiopia are unique in Africa and home to high proportions of endemics. The Ethio- 


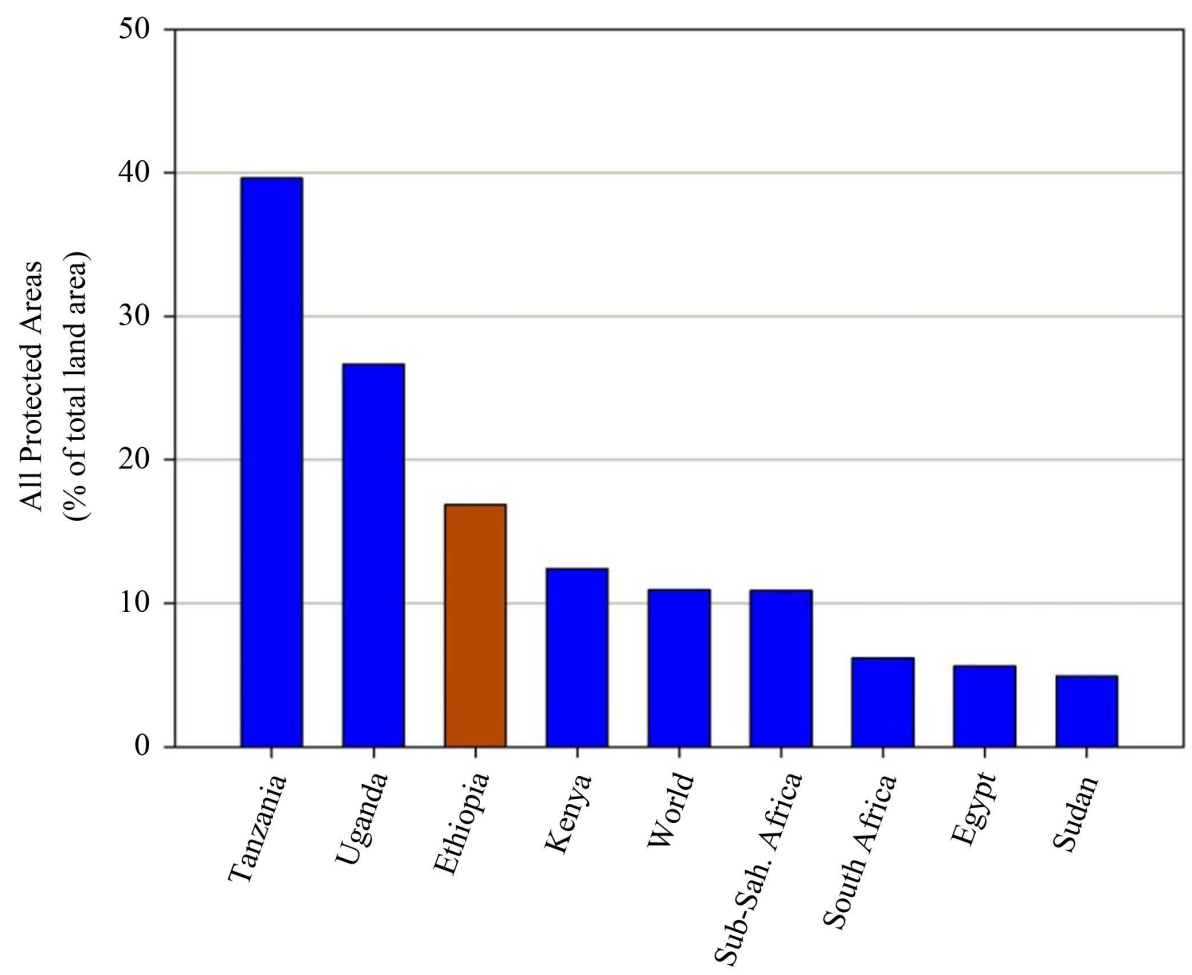

Figure 1. Comparison of land surface within protected areas of Ethiopia with other country.

Protected areas expansion over time

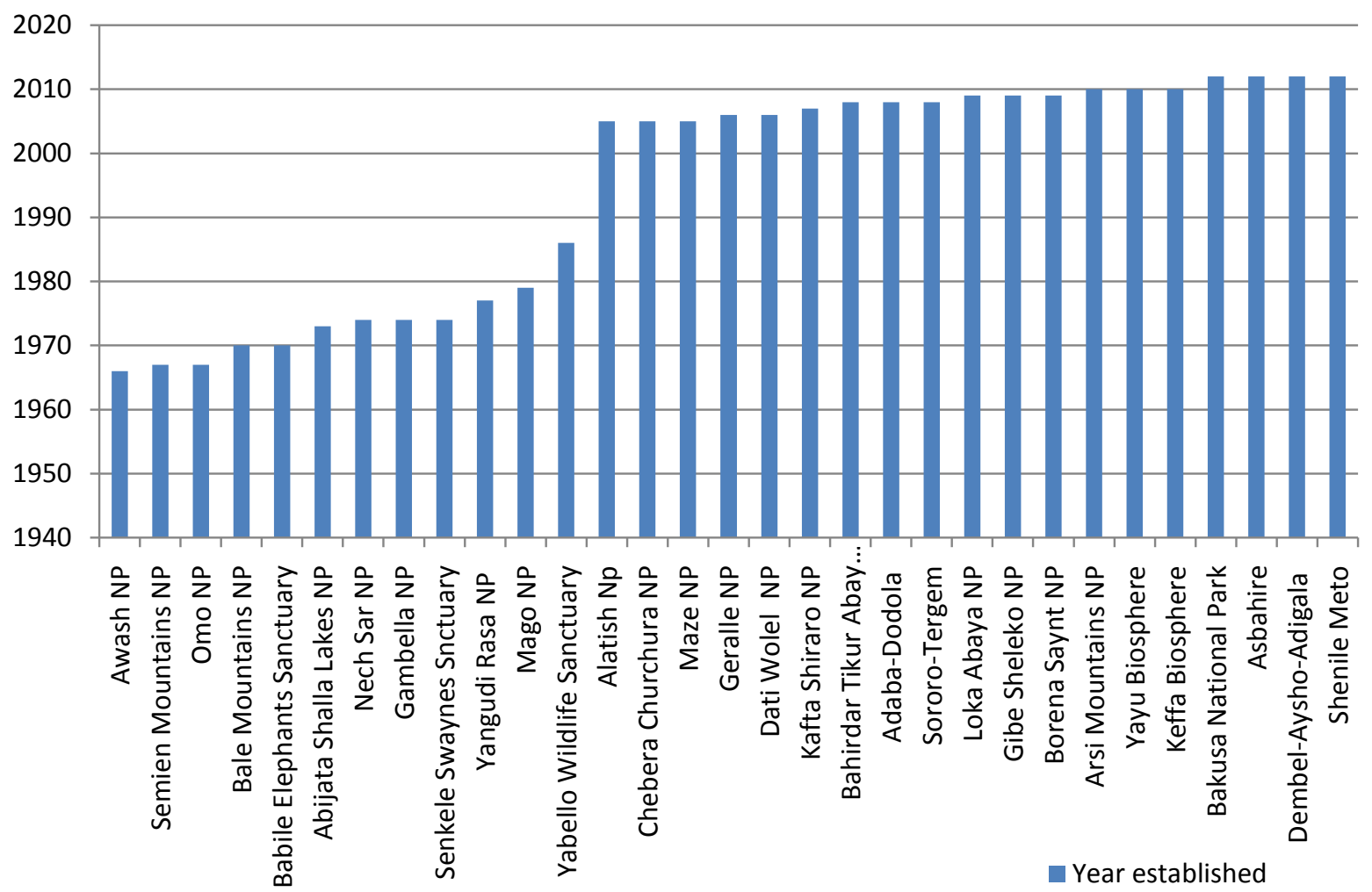

Figure 2. Protected area development of Ethiopia. 


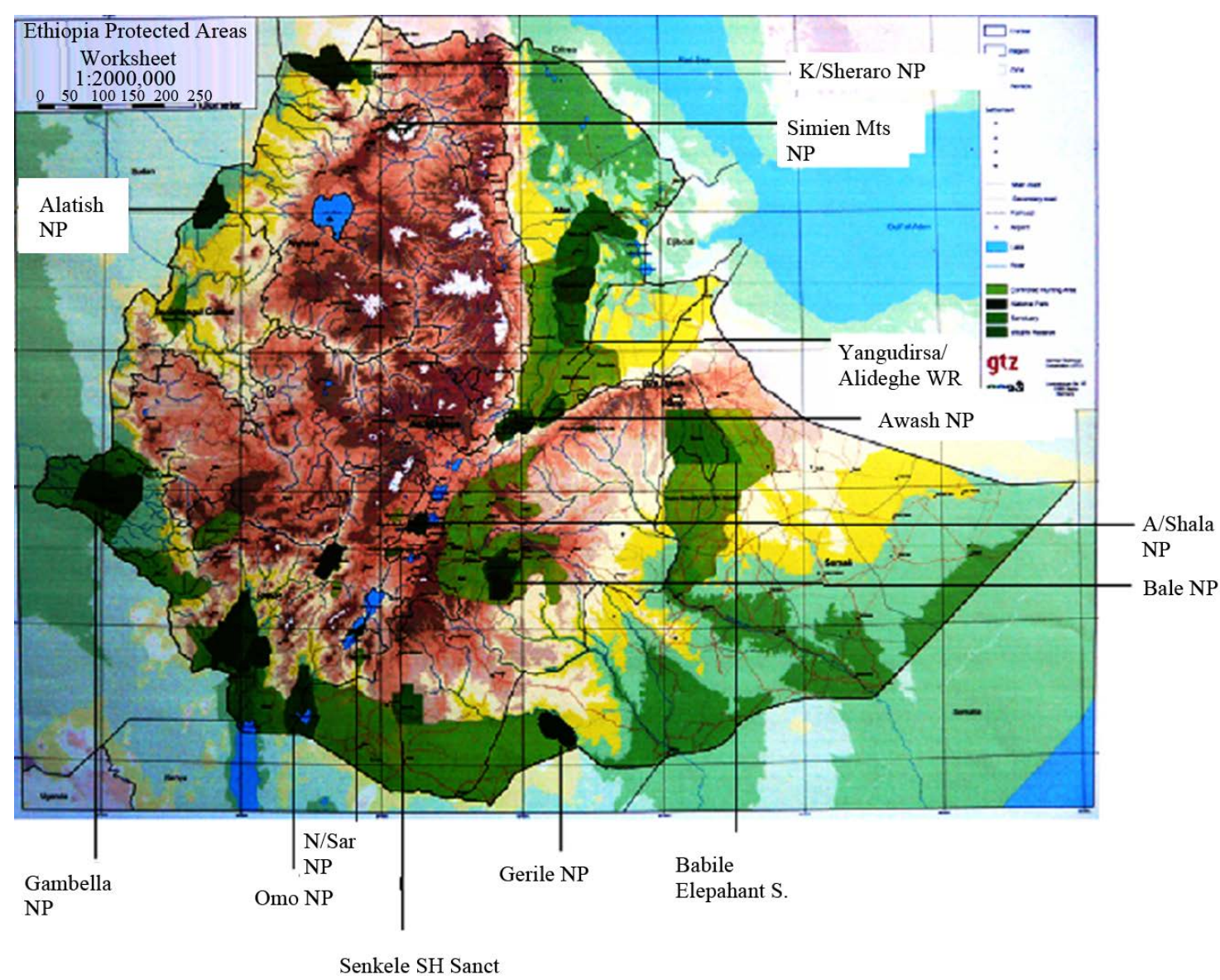

Figure 3. Geographical location of protected areas in Ethiopia (Source; EWCA).

Table 2. Overall protected areas of Ethiopia.

\begin{tabular}{ccccc}
\hline No & Protected Area & Federal & Region & Total \\
\hline 1 & National Parks & 11 & 10 & 21 \\
2 & Wildlife Sanctuaries & 2 & 1 & 3 \\
3 & Wildlife Reserves & 1 & 2 & 3 \\
4 & Controlled Hunting Areas & - & 18 & 18 \\
5 & Open Hunting Areas & - & 7 & 3 \\
6
\end{tabular}

Source: [10].

Table 3. Selected flagship protected area of the country.

\begin{tabular}{cc}
\hline Eco-Region & Focal Protected Areas \\
\hline Montane \& Afroalpine & Bale Mountains National Park \\
& Simien Mountains National Park \\
Great Rift Valley & Chebera Churchura National Park \\
& Nech-Sar National Park \\
Transboundary Migratory Ecosystem & Senkelle Swayne's Hartebeest Sanctuary \\
\end{tabular}


pian highlands consists of Afroalpine ecosystem and mountainous vegetation vary with coniferous and broadleaved forests and ericaceous vegetation types. The Afroalpine ecosystem contains protected areas including Bale Mountains National Park and Simien Mountains National Park and described below.

1) Bale Mountain National Park

a) Unique features

Bale Mountains National Park (the largest Afroalpine ecosystem in Africa) is encompassed within geographical coordinates of $6^{\circ} 29^{\prime} \mathrm{N}-7^{\circ} 10^{\prime} \mathrm{N}$ and $39^{\circ} 28^{\prime} \mathrm{E}-39^{\circ} 57^{\prime} \mathrm{E}$. The park includes a major Afro alpine plateau over $3500 \mathrm{~m}$ above sea level as well the slopes to the south that include low land tropical moist forest down to 1500 $\mathrm{m}$ above sea level. The presence of largest Afroalpine habitat in Africa, steeper slope of the forest on Harenna escarpment, Mount Batu, Sanetti Plateau, Erica with giant plant lobelia and ecosystem of the park attracts numerous tourists. The park's habitat can be divided into five habitats: the Northern Grasslands (Gaysay Valley), Northern Woodlands (Park Headquarters), Afro-alpine Meadows (Sanetti Pleateau), Erica Moorlands, and the Harenna Forest. A large part of the park ranged from 3000 to $4377 \mathrm{~m}$ above sea level and this is the second highest peak of Ethiopia next to Ras Dashen of northern highlands. Tulluu Dimtu is the highest peak of the park delivers excellent view for tourists [17].

b) Key species contributed for tourism

The mountains provide habitat and home of the endemic and endangered species (presented on Figure 4). It is home for five endemic mammals namely, Ethiopian wolf (Canissimensis) and Mountain nyala (Tragelaphus buxtoni), Menelik's bushbuck (Tragelaphus scriptus meneliki), Bale monkey (Chlorocebus djamdjamensis) as well as giant mole rat (Tachyoryctes macrocephalus). Therefore, itis among top visited park in Ethiopia due to its charismatic and endemic mammal species composition, and plays vital for tourism industry [17]. Besides these endemic mammals, the park is one of the most important birdareas in Africa [33]. Moreover, the mountains offer great opportunities for mountain trekking, horse trekking, and scenic driving.

2) Simien Mountains National Park (SMNP)

a) Unique features

Simien Mountains National Park is located on geographical coordinates about $13^{\circ} 9^{\prime} \mathrm{N}$ and $38^{\circ} 15^{\prime} \mathrm{E}$ with an area of about $233 \mathrm{~km}^{2}$ adjacent to Mt. Ras Dashen, the highest summit of the country and the fourth highest peak in Africa. It has been created due to mass erosion over the years of Ethiopian plateau which is spectacular landscapes in the world, with beautiful mountain peaks, deep valleys and sharp cliffs dropping some 1500 meter above sea level. The park is the most beautiful mountain area in the world and occupies chains of plateau and grassy plains [34] (Figure 5).

The park has a global impact for biodiversity conservation because of it is home to globally threatened and flagship species, including the iconic Walia ibex, a wild mountain goat found nowhere else in the world, the Gelada baboon and the Ethiopian wolf and therefore, those mammals contribute for tourism industry [16]-[18]. The presence of large number of endemic species, unique bio-physical features, and its international significance made Simien Mountains National Park to become one of the World Heritage Sites in 1978. Moreover, the area of wonderful topographical features on "the roof of Africa" with opportunities for viewing life of the local people, trekking, mountain hiking and ecological studies on the park has excellent potential for tourist attraction. The park is listed as one of the important bird areas in Ethiopia, more than 180 species of birds are recorded and some of them are endemic to the country [17].

\subsubsection{The Great Rift Valley Protected Areas of Ethiopia}

The magnificent of the Great Rift Valley in Ethiopia consists of both aquatic ecosystems including lakes, rivers and giant waterfalls, and terrestrial with savannah crowded with game, dense and wonderful bush land area [8]. The Rift Valley ecosystem includes more than 15 protected areas from Yangudi-Ras National Park in the north to Omo National Park in the south which contains spectacular landscapes, lakes and forests with highly diverse communities of plants and animals, and many volcanic features. For this paper, I selected two national parks (Chebera Churchura National Park and Nech-Sar National Park) and one sanctuary (Senkelle Wildlife Sanctuary) due to their scenic features and the presence high mammal diversity [35].

1) Chebera Churchura National Park (CCNP)

Chebera Churchura National Park is one of the recently established in 2007 protected areas and located about 330 and $460 \mathrm{~km}$ southwest of Hawassa and Addis Ababa, respectively [17]. It found within the western side of 


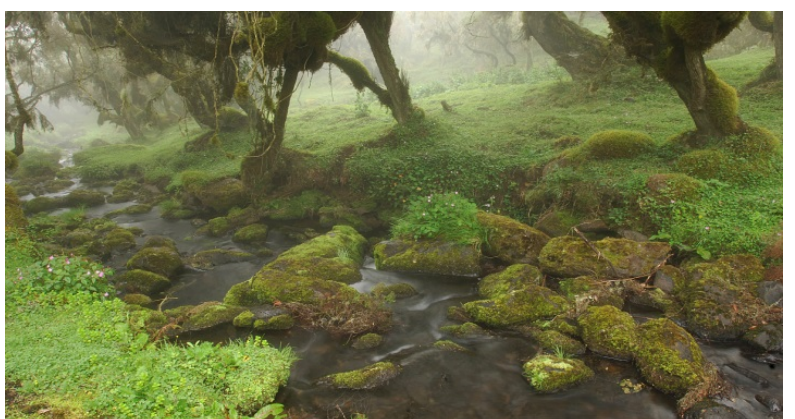

(a)

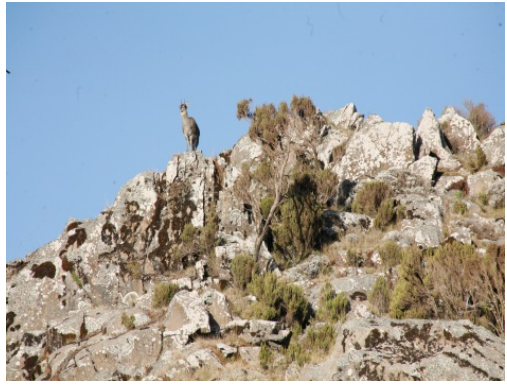

(c)

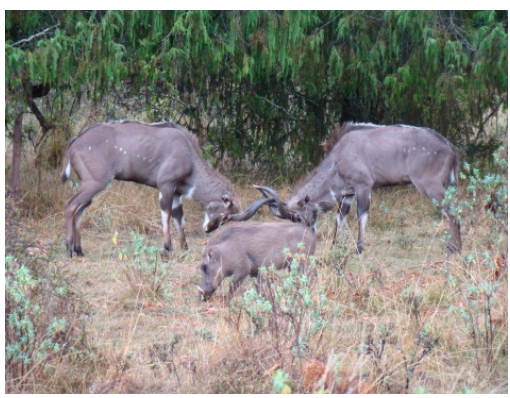

(f)

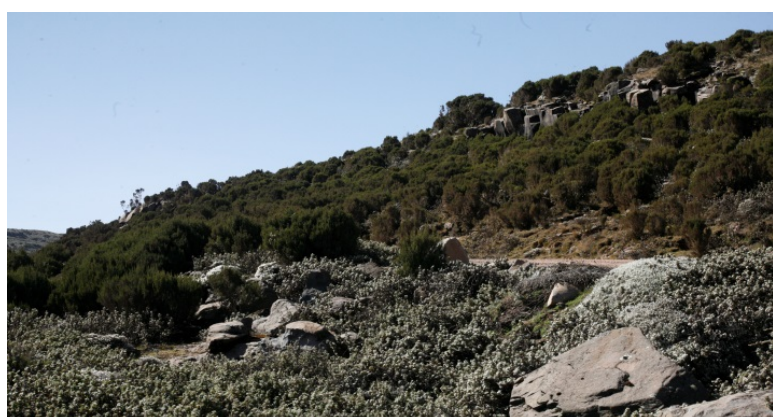

(b)

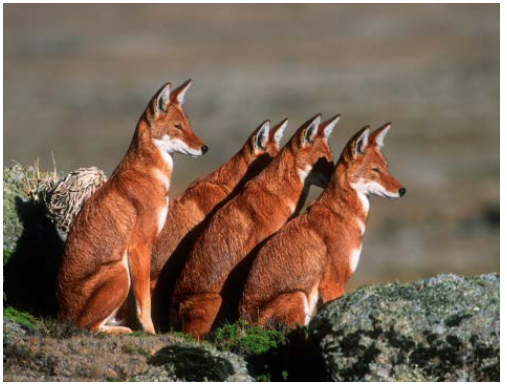

(d)

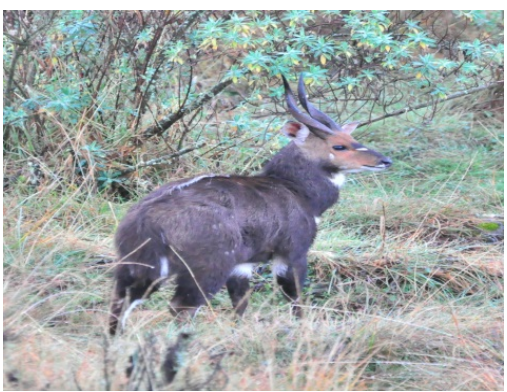

(g)

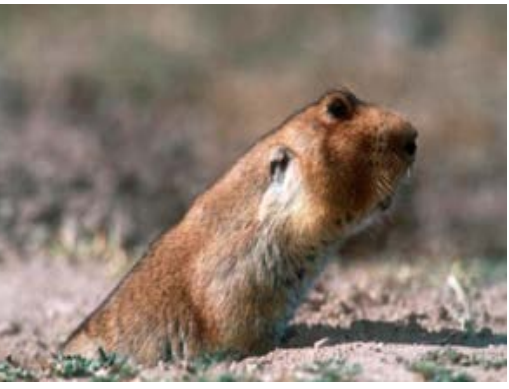

(e)

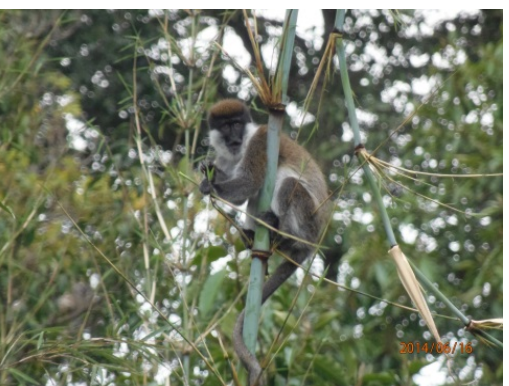

(h)

Figure 4. Partial view and large endemic mammals of the Bale Mountains National Park; (a) \& (b) Landscape of the park, (c) Klipspringer, (d) Ethiopian wolf, (e) Giant mole rat, (f) Mountain nyala and warthog, (g) Menelik bushbuck, (h) Bale monkey (Photo by Alemneh Amare, 2014; EWCA (d)).

the central Omo Gibe basin of Rift Valley in the Southern Nation Nationalities Peoples and Regional State, Ethiopia. It lies between $36^{\circ} 27^{\prime} 00^{\prime \prime} \mathrm{E}-36^{\circ} 57^{\prime} 14^{\prime \prime} \mathrm{E}$ and $6^{\circ} 56^{\prime} 05^{\prime \prime} \mathrm{N}-7^{\circ} 08^{\prime} 02^{\prime \prime} \mathrm{N}$ and covers an area of $119 \mathrm{~km}^{2}$ with altitudinal range of 700 - $2400 \mathrm{~m}$ above sea level [17] [36].

The vegetation of the park can be divided in to four categories; montane forest, riverine forest, woodland and grassland vegetation types with high species composition. Its topographic feature is characterized by unique and very attractive with highly heterogeneous and hilly terrain, few flat lands and highly undulating to rolling plains with incised river and perennial streams, valley and gorges.

a) Fauna as a key species

The exceptional and variety of habitat hosts about 37 larger mammals and 237 species of birds in the park. Five large mammals "big five" species occur namely; African elephant (Loxodonta africana), African buffalo (Syncerus caffer), Lion (Panthera leo) and Hippopotamus (Hippopotamus amphibious) in the park. In addition to these key species, Gureza (Colobus guereza), Bush baby (Gelago senegalensis), Savanna baboon (Papio cynocephalus), Warthog (Phacochoerus africanus), Bushbuck (Tragelaphus scriptus), Bushpig (Potamocherus larvatus), Waterbuck (Kobus ellipsipprymus), Common duiker (Sylvicapra oreotragus), Golden jackal (Canis aureus), Honey badger (Mellovora capensis), African civet (Civettictis civetta), White tailed mongoose (Ichneumia albicauda), Spotted hyena (Crocuta crocuta), Leopard (Panthera paradus), Aardvark (Orycteropus afer), 

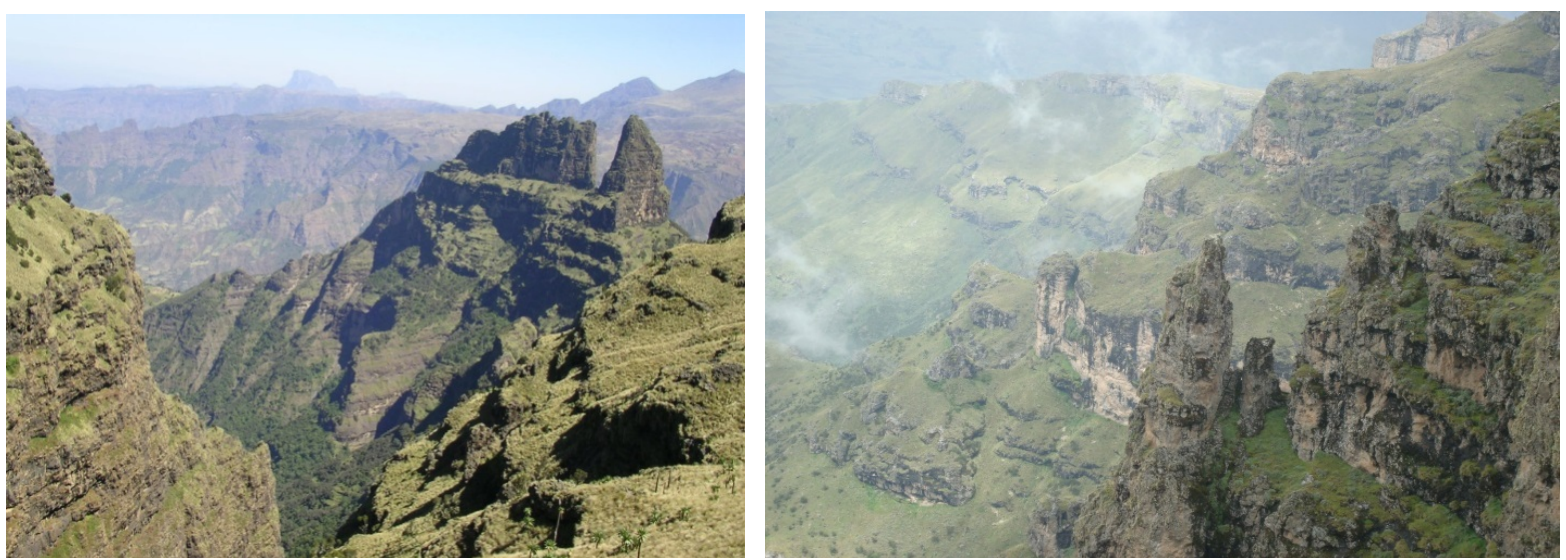

(a)

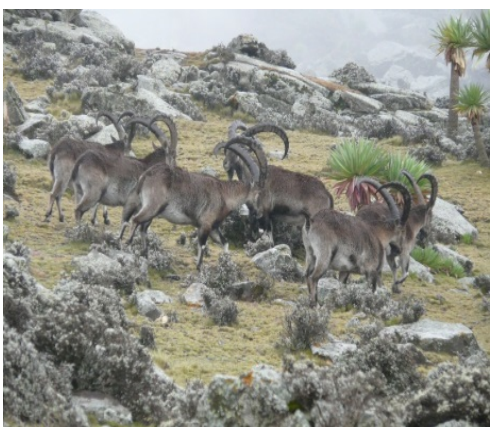

(b)

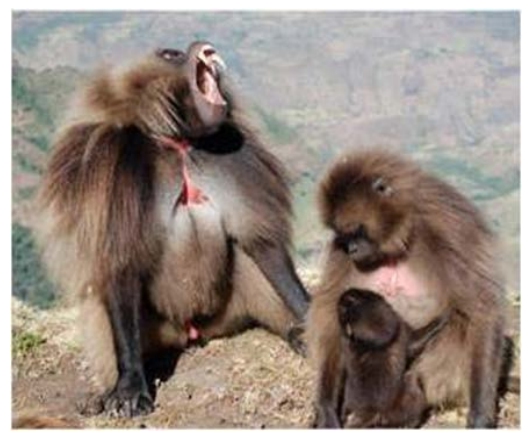

(c)

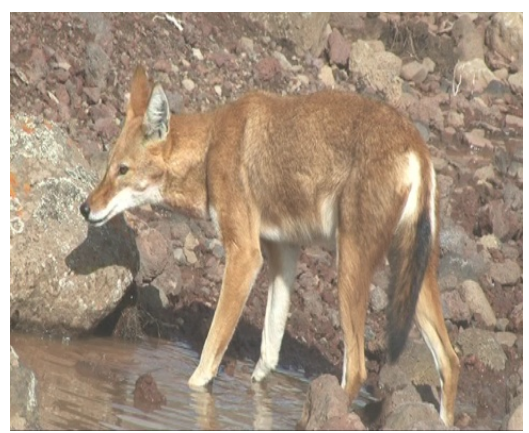

(d)

Figure 5. Partial view \& large endemic mammals of Simien Mountains National park; (a) View ofthe park, (b) Walia ibex, (c) gelada baboon (male, female \& neonate), (d) Ethiopian Wolf (Photo by Alemneh Amare, 2013).

Ground squirrel (Xerus erythropus), Porcupine (Hystrix cristata) and Nile crocodiles were some of the mammals recorded in the park [17] [36] [37] (Figure 6). Furthermore, out of varieties of bird species, White-cliff chat, Banded-barbet, Wattled ibis, Black-headed forest oriole and Thick billed raven are endemic species found in the area. Therefore, the presence of wilderness area with high mammalian diversity in chained mountain forest, tall-grassed savannah habitat, thick woodland forest, number of cold and hot springs and rivers, and historical caves are potential destination for tourists.

2) Nech-Sar National Park

Nech-Sar National Parkis among IUCN category II National Park in Ethiopia and established in 1974 to conserve the endemic Swayne's hartebeest and other key species as well as preserving its scenic beauty (Figure 7). It is situated at $510 \mathrm{~km}$ south of Addis Ababa near Arbaminch town. This Rift Valley protected area covers about $514 \mathrm{~km}^{2}$ with elevation point ranged from 1108 to $1650 \mathrm{~m}$ above sea level. The park is surrounded by the Amaro Mountains in the east, north by Lake Abaya, and south by Lake Chamo and one of the best destinations of safari tourism in Ethiopia [17]. These two lakes support stocks of Nile perch and Cat fish.

The park's landscape includes extensive grasslands, savannah, mountains and hills and has a variety of habitats ranging from savannah, dry bush and ground water forests. Most of the park is covered in thick bush land with wooded valleys and foothills at the base of the Amaro Mountains. About 15\% of the park consists of Lake Abaya and Chamo around that contributes groundwater forest and shoreline habitats, home for aquatic dependent animals [38]. Furthermore, the two major rivers, Sermule and Kulfo traverse the park and support variety amphibians.

a) Dominant flora of the park

The beautiful and diverse evergreen habitat which is dominated by large trees such as the Giant figs, Ficus sycomorus and Ficus vasta, forest mahogany, Trichilia dregana, and the Sermule Valley characterized by classic dry season habitat with large umbrella acacias (Acacia tortilis) and sycamore figs (Ficus sycomorus). Freshwater springs attract variety of butterflies and dragonflies some of them are endemic species. 


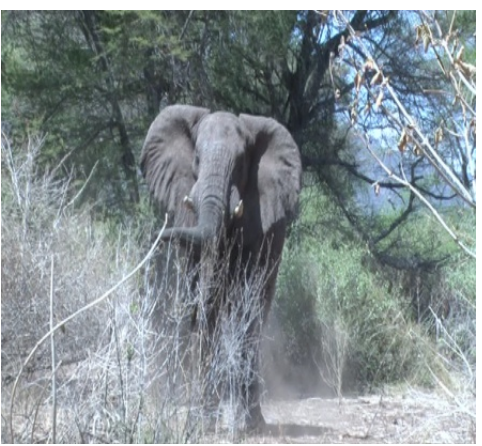

(a)

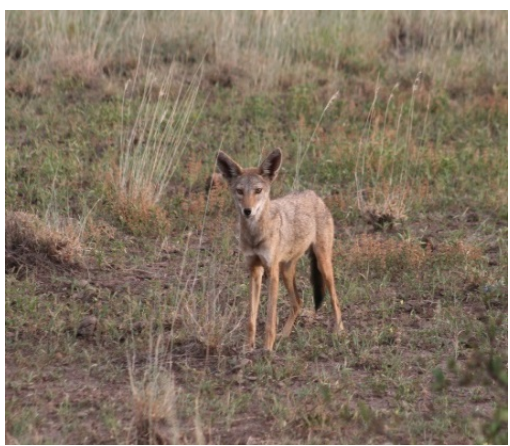

(d)

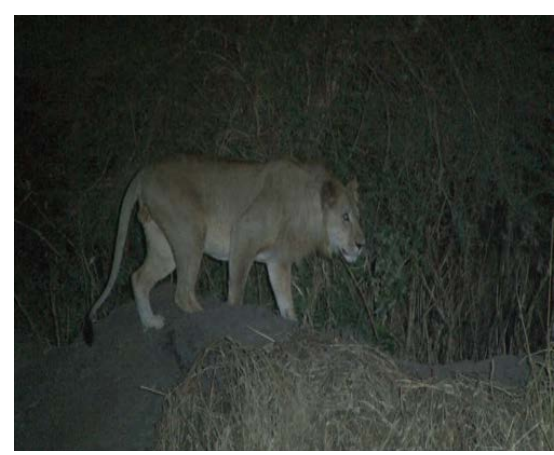

(b)

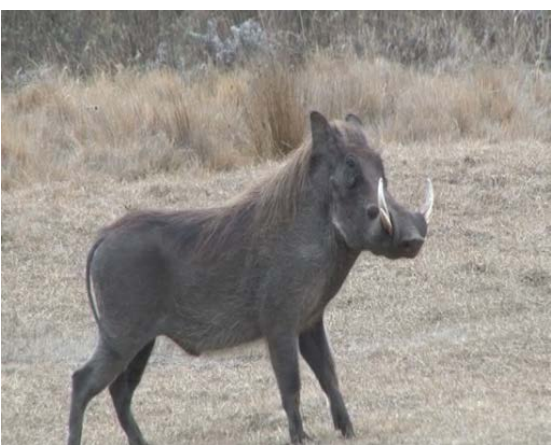

(e)

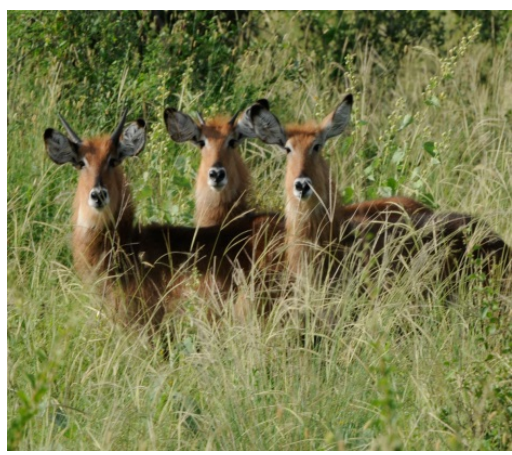

(c)

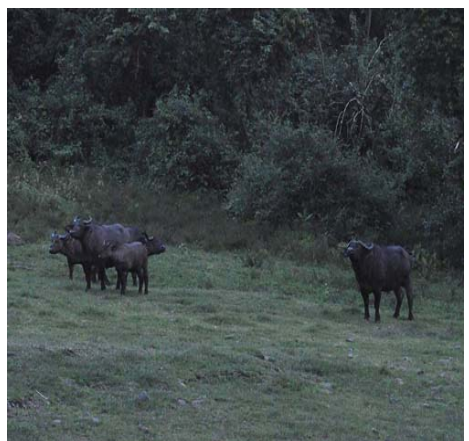

(f)

Figure 6. Few large mammals in Chebera Churchura National Park; (a) African elephant, (b) Lion, (c) Waterbuck, (d) Common jackal, (e) Warthog, (f) African buffalo (Photo from Ethiopian Wildlife Conservation Authority).

b) Fauna and key species

The aquatic and terrestrial ecosystem of Nech-Sar National Park harborsmore than 37 mammals and 330 bird species. Among these large mammals, Swayne's hartebeest (Alcelaphus buselaphus swaynei), Burchell's zebra (Equus burchelli), Grant's gazelle (Nanger granti), Waterbuck (Kobus ellipsipprymus), Warthog (Phacochoerus africanus), Bohor reedbuck (Redunca redunca), Oribi (Ourebiaourebi), Greater kudu (Tragelaphus strepsiceros), Common Bushbuck (Tragelaphus scriptus), Guenther's dik-dik (Madoqua guentheri), Grey Duicker (Sylvicapra grimmia), Bush duiker (Sylvicapra oreotragus), Bush pig (Potamocherus larvatus), and Hippopotamus (Hippopotamus amphibious). Lion (Panthera leo), Leopard (Panthera paradus), Serval cat (Leptailurus serval), Spotted hyena (Crocuta crocuta), Common jackal (Canis aureus) and Nile crocodile (Crocodylus niloticus) are the major predators recorded in the park (Figure 7). Four primate species, Anubis baboon (Papioanubis), Vervet monkeys (Chlorocebus pygerythrus) and Black and white colobus monkey (Colobus guereza), 19 bat species recorded in Nech-Sar National Park. The avifauna including kingfishers, storks, pelicans, flamingos and fish eagles as well as for its migratory birds, and few birds including Wattled ibis, and Nech-Sar Nightjar are endemic species found in the park [17].

c) Attractive features of the park

The presence of many large mammals and avifaunal diversity with two major lakes; Abaya and Chamo, Nech-Sar plain, Rift Valley escarpment, 40 hot springs nearby, white creamy grass covers the central plains, the "crocodile market" located on the northwestern shores of Lake Chamo attracts both local and international tourists.

3) Senkelle Wildlife Sanctuary

Senkelle Wildlife Sanctuary is one of the best tourist destination protected areas found in the Great Rift Valley of Ethiopia. It is located between $7^{\circ} 10^{\prime} \mathrm{N}$ and $38^{\circ} 15^{\prime} \mathrm{E}$, and on the western side of the Great Rift Valley, west of Hawassa and $320 \mathrm{~km}$ south of Addis Ababa. The Sanctuary was established in 1976 to protect the endemic and endangered antelope species, Swayne's hartebeest (Alcelaphus buselaphus swaynei), and currently covers $54 \mathrm{~km}^{2}$ [35] (Figure 8).

a) Faunas and habitat types 


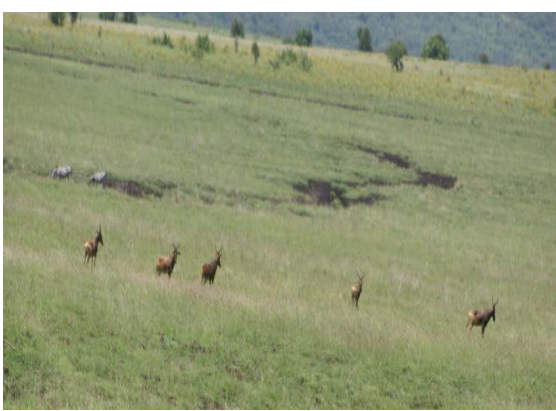

(a)

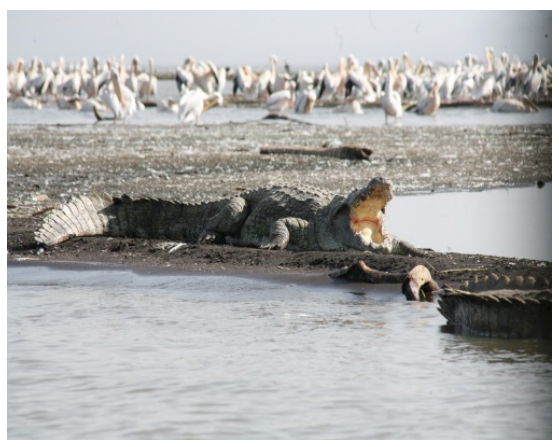

(d)

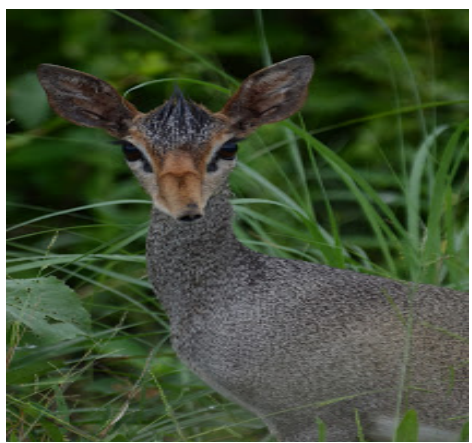

(g)

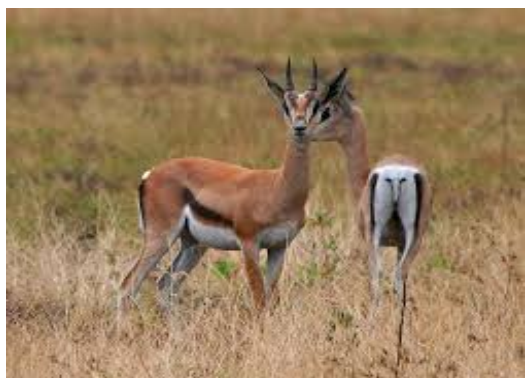

(j)

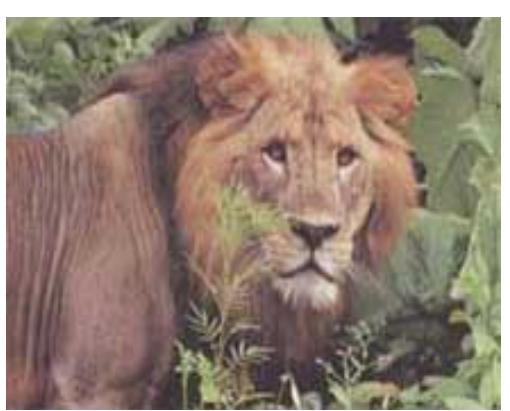

(b)

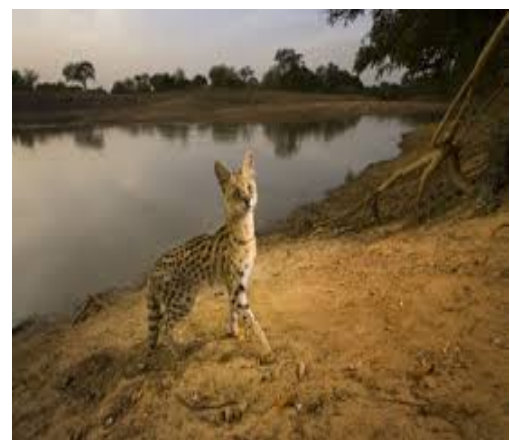

(e)

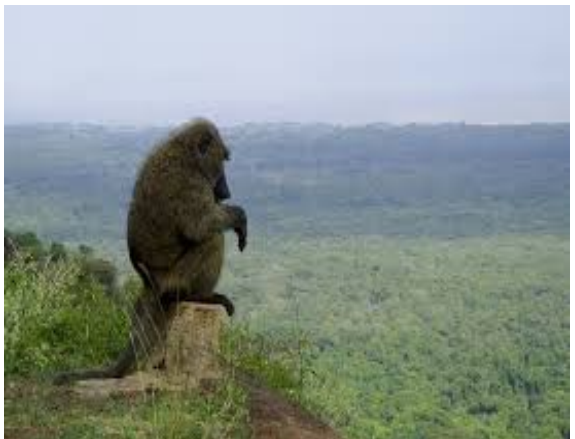

(h)

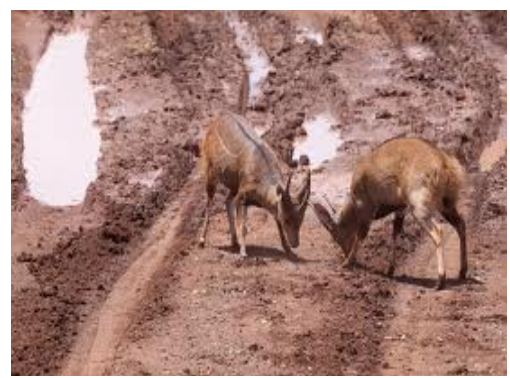

(k)

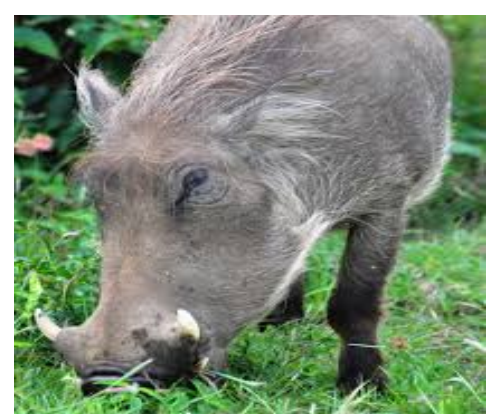

(c)

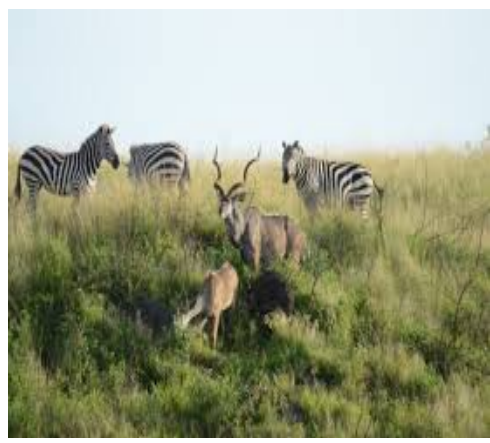

(f)

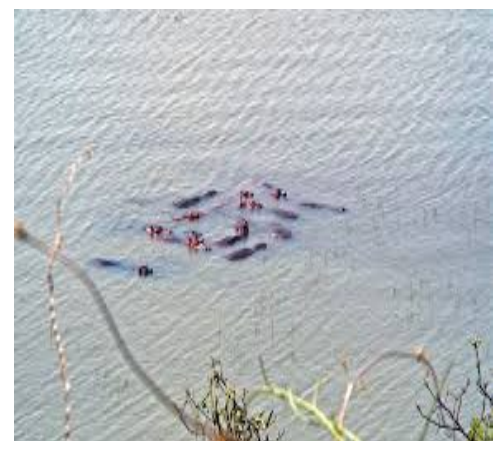

(i)

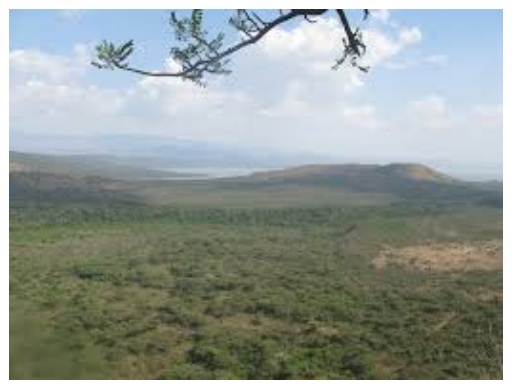

(l)

Figure 7. Few large animals found in Nech-Sar National Park; (a) Swayne’s hartebeest, (b) Lion, (c) Warthog, (d) Crocodile and pelicans, (e) Serval cat, (f) Greater kudu and Zebra, (g) Guenther's dik-dik, (h) Anubis baboon, (i) Herd of Hippopotamus, (j) Grant's gazelle, (k) Common bushbuck and (l) partial landscape of the park (Photo by Alemneh Amare \& EWCA, 2013/4).

The sanctuary characterized by montane savannah and acacia woodland habitat is quite scenic with Tesisa, Borena and Lalima hills and mountainous view. Swayne's hartebeest is one of the flagship species to the sanctuary and it harbors other wild animals including Bohor reedbuck (Redunca redunca), Lion (Panthera leo), Greater 


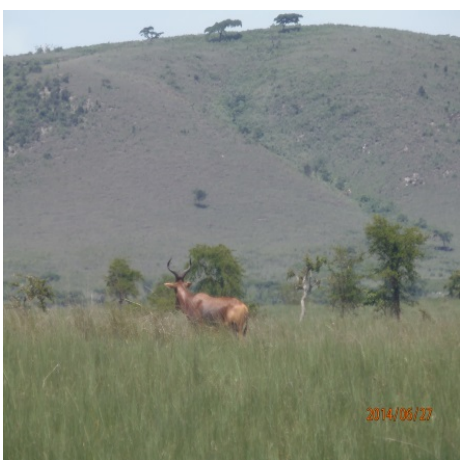

(a)

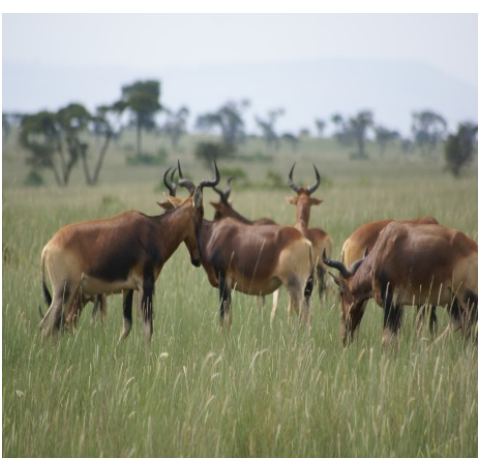

(b)

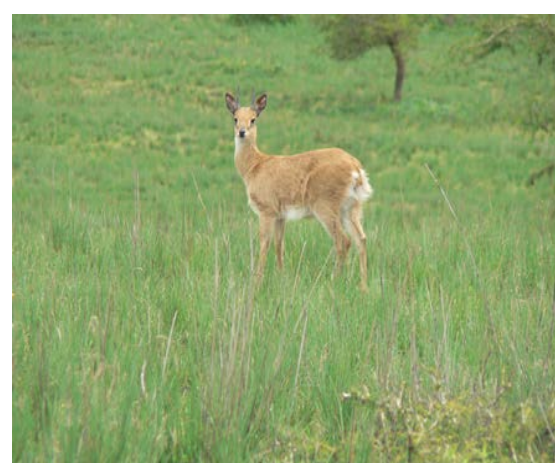

(c)

Figure 8. Some of the key species in Senkelle Wildlife Sanctuary; (a) Swayne’s hartebeest (Adult males \& females), (b) Oribi (adult male \& female).

kudu (Tragelaphus strepsiceros), Oribi (Ourebia ourebi), Spotted hyena (Crocuta crocuta), Servalcat (Leptailurus serval), Civet cat (Civettictis civetta), Caracal (Caracal caracal), Warthog (Phacocoerus aethiopicus), Grivet monkey (Chlorocebus aethiops), Crested porcupine (Hystrix cristata), Aardvark (Orycteropus afer), Abyssinian hare (Lepush abessinicus) and common jackal (Canis aureus) (Figure 8) as well as more than 91 species of bird [35]. The current population of Swayne's hartebeest is about 800 individuals (Warden's communication). Moreover, game driving; wildlife viewing, scenic views and wilderness camp with bird watching activities, acacia shade with musical songs of various bird species are the most exciting and opportunistic occasion to visitors.

\subsubsection{The Southwestern Transboundary Ecosystem}

1) Gambella National Park (GNP)

Gambella National Park founds on at the edge of southwestern lowlands of Ethiopia and established in 1974 to conserve a diverse assemblage of wildlife and unique habitats particularly key species (Figure 9). Prior to its established year, the park was created to protect extended swampy habitats on Akobo River with its wildlife. The park located on central coordinates $\left(34^{\circ} 0.00^{\prime} \mathrm{E}\right.$ and $\left.7^{\circ} 52.00^{\prime} \mathrm{N}\right)$ and $840 \mathrm{~km}$ west of Addis Ababa and covers a total area of $5061 \mathrm{~km}^{2}$ with average altitude is about $550 \mathrm{~m}$ above sea level. Gambella National Park also supports extensive areas of wet grassland and swamps where the native grasses grow over 3 meters in height [6].

a) Wildlife diversity of the park

Gambella National Park’s vegetation covered by shrub lands, flood plains, woodland and forest with long savannah grasses. The park is very undistinguished from other protected areas of the country by transboundary habitats and hosts numerous migratory ungulates [16]. A large migratory population of White-eared kob migrates to and from Boma National Park in South Sudan, neighboring country of Ethiopia. Approximately, more than half million population of animals migrates and ranked the second migration in Africa next to the Serengeti wildebeest migration in Tanzania.

Gambella National Park has a variety of wildlife; more than 41 large mammals and 300 bird species of which 11 are Sudan-Guinea Biome species. The most common large mammals found in the mixed habitats are African elephant (Loxodonta africana), African buffalo (Syncerus caffer), Lion (Panthera leo), Warthog (Phacochoerus africanus), Bushbuck (Tragelaphus scriptus), Giraffe, Taing (Topi), Bush pig (Potamocherus larvatus), Spotted hyena (Crocuta crocuta), Waterbuck (Kobus ellipsipprymus), Nile lechwe, Burchell's zebra.The swampy and savanna-dwelling species hosts many mammals such as the Nile lechwe (Kobus megaceros), White-eared kob (Kobus kob leucotis), Roan antelope and Bohor reedbuck (Redunca redunca), while primates include the Patas monkey (Erythrocebus patas) [16].

In other hand, Hippopotamus (Hippopotamus amphibious), Nile crocodiles and perch, and other freshwater fishes, amphibians and reptiles hosted by rivers at Gambella National Park. Furthermore, variety of fresh water fishes, amphibian and reptile species are found in this region [16].

b) Unique features

The flat landscape that supports deciduous woodlands, grassland vegetation and plain games, and perhaps be one of the best wildlife areas of the country. It also has high set of Wildlife, which the country shares with neighboring countries including White-eared kob, Nile Lechwe, Roan Antelope, Topi and Elephant. Further- 

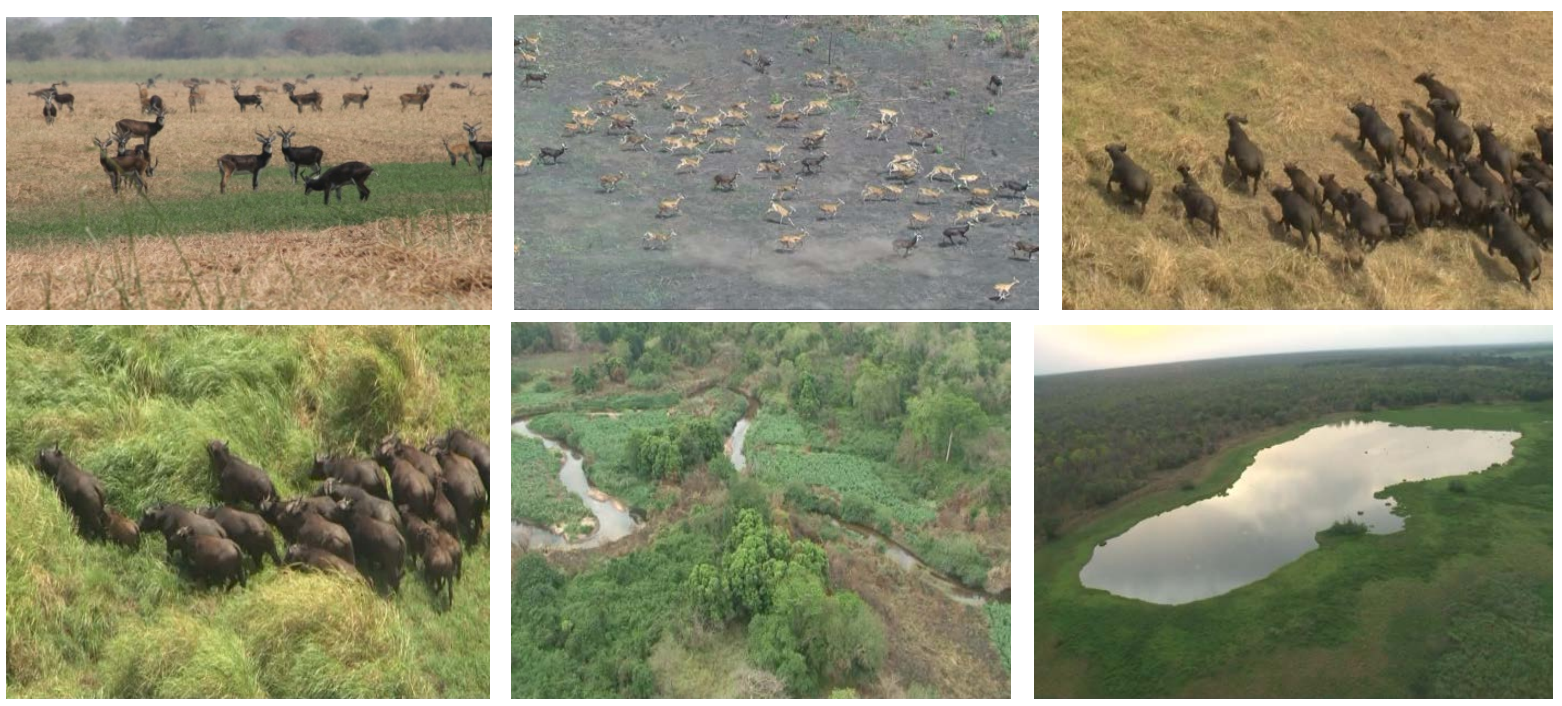

Figure 9. Some of the landscape and wildlife of Gambella National Park.

more, the near threatened Shoebill and Basra Reed Warbler have been recorded. The area holds 11 Sudan-Guinea Biome species holding $69 \%$ of Ethiopia's total assemblage for this category. The largest wetland area and four major rivers crossing the park (Baro, Alwero, Gilo, Akobo) is one of the tourist destination sites in Ethiopia.

\subsection{Peace and Security Promotes Wildlife Tourism}

Other important aspects for tourism industry are peace and security of either the site or country, where tourists hosted. The multi-cultural and great hospitality of people with various ethnic groups who speak their own language and identity in every corners as well as variety of religious ceremony have its own contribution for tourism development. In East Africa, Ethiopia, Rwanda, Tanzania and Uganda are likely to achieve growth of between $6.5 \%$ and $7.5 \%$ in 2014/15 [39]. In contrary, growth in Sudan continues to remain passive and violation due to disruptions and ongoing conflicts. Furthermore, the economy of the Central African Republic is heavily affected by the political and security conflict, and prospects remain uncertain [39]. Therefore, the absence of conflict and terrorist or peaceful and security play an important role to promote sustainable nature based tourism which directly affects country's economy. Political stability and security is one of the essential prerequisites for attracting international tourists to a destination. In the contrary, violent protests and civil wars will cause damage to infrastructure and tourists to cancel their leisure to the country [40]. Hence, the number of visitors towards protected area is increasing in Ethiopia (Figure 10).

\section{Challenges of Wildlife Tourism}

\subsection{Loss of Biodiversity}

Many protected areas in Ethiopia are threatened due to ever increasing of population, habitat loss and degradation [19]. Land use changes through agriculture, rural and urban development activities have led to the decline and alteration of wild areas, resulting in the extinction to wildlife species and natural areas which serve as their habitat. I tried to address some of the root causes of losses of biodiversity which directly impose wildlife tourism and biodiversity conservation.

\subsection{Human Wildlife Conflict}

Conflicts over natural resources between the communities living adjacent to protected area and tourism development have increased in recent years because of changes in land use and accompanying new ideas about wildlife resource management and utilization [41].

The varieties of large animals in Ethiopia are many and their distributions are dependent on the protected 


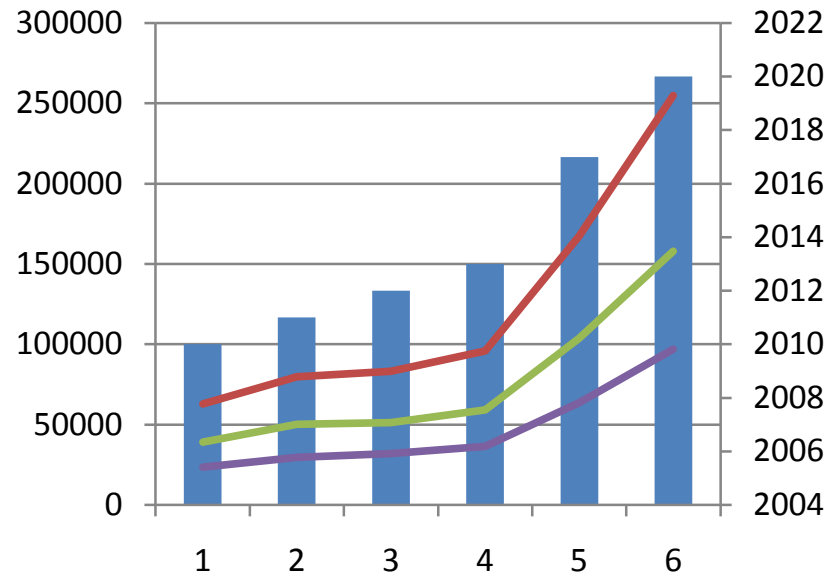

areas (primarily on national parks and sanctuaries) with insufficient protection [19]. Currently, these protected areas are highly threatened by anthropogenic effects. Human-wildlife conflict is a major concern of most people living next to protected areas in developing countries due to their subsistent live [4] [12]. It arises when growing human populations needs overlap with protected areas and results scrambling for resource. As the Ethiopia's population increases, there is an increasing demand for space and resource utilization and affects wild animal's habitat on the protected areas. For example, in Simien Mountains National Park, the population of Walia ibex has decreased due to agricultural expansion affects their habitat [34]. The endemic gelada baboon was the major causes of conflict with local communities because of their farmlands in these villages were located close to the habitat of gelada baboons [34]. In the same scenario, the Senkelle Wildlife Sanctuary's total area were $200 \mathrm{~km}^{2}$ with more than 3000 population of Swayne's hartebeest during 1972 and but currently shrunken to only 54 km $^{2}$ with 800 population due to population growth and agricultural expansion [35] [42] (Figure 11).

\subsection{Deforestation and Forest Degradation}

Deforestation resulting land degradation is the global threats for many wild animals with its natural habitat and affects the wild animal's life style in their preferred habitats. The forest cover of Ethiopia has been approximately $40 \%$ of its land a century ago but now has declined to only 3\% [43]. The extensive deforestation has also led to the extinction of various biot as resulting in significant biodiversity loss. Now, more than $17.1 \%$ of the country's land is protected area. However, much of this is forest land that is now widely used for cultivation, grazing, fuel wood and construction. Restricting the comparison to category I and II protected areas (i.e. National Parks and Wilderness Areas) approximately $2.7 \%$ of the land surface is only protected at this level which is lower than its neighbor country (Figure 12). The human population around most protected areas over the years has been changing in terms of its size, density and livelihood strategies [44]. Uncontrolled logging, illegal charcoal production and fuel wood collection are some of the major causes of deforestation that directly influence large mammal's habitat, where tourism is dependent. Moreover, such activities impose to decline the scenic beauty of the protected area which also affects tourism and wilderness (Figure 13).

\subsection{Poaching}

Poaching and illegal wildlife trade activities in and around the park, as well as the unwise use of natural resources have been the major problems facing the park and have led to the extinction of some fauna species [45]. It leads to detrimental environmental, economic and social consequences. Over time, the international community has become aware of the fact that poaching is the most immediate and direct threat to wildlife in Africa making its upward trend a cause of serious concern. In some parts of Ethiopia like Gambella, Ethiopian Somali and Afar areas, poaching has been practiced for income generation and agricultural practices [46] (Figure 14).

During the 1970s, trophy hunting was also conducted on a large scale in Ethiopia, though since then, aggregate human populations, political instability and encroachment on wildlife habitat have resulted in a $95 \%$ de- 

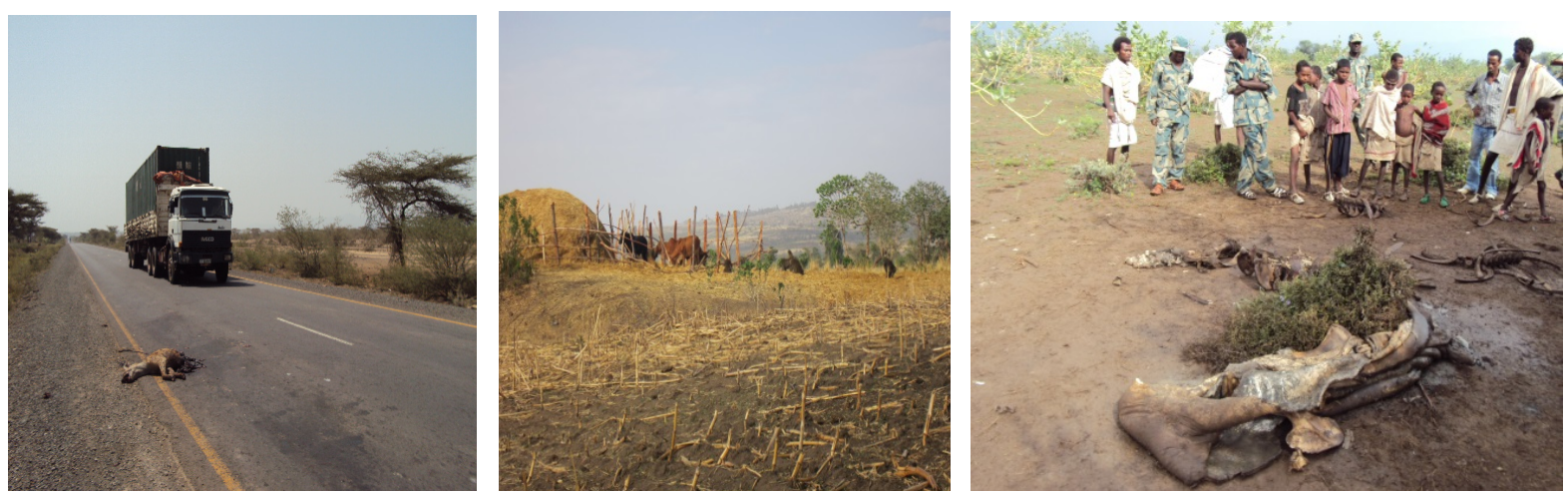

Figure 11. Some pictures of human wildlife conflict.

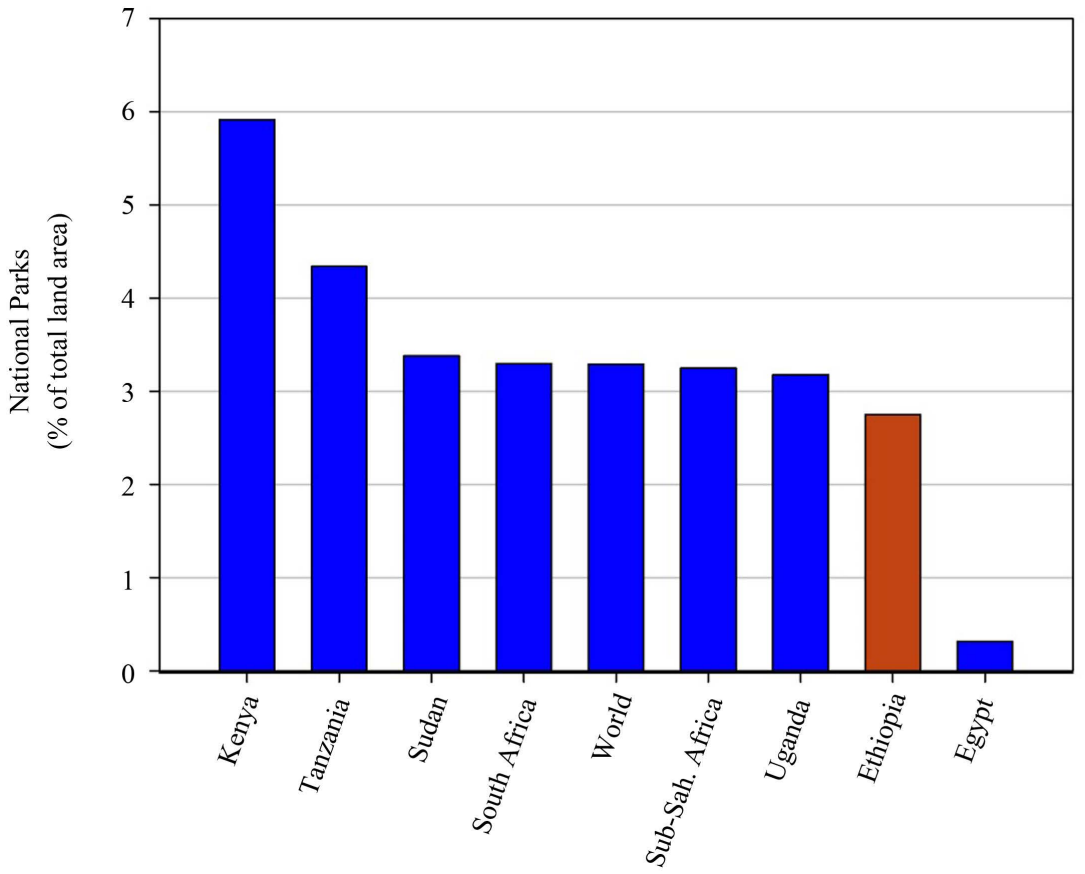

Figure 12. Land surface area that is within National Parks (IUCN Categories I \& II) of Ethiopia and some of its neighbors.

crease in the area used for trophy hunting. Trophy-animal hunting (e.g. elephant or buffalo) accumulate high revenue for safari hunters and provide income for the rural resident communities. Mountain nyala (Tragelaphus buxtoniis) is the most commonly species used by operators to attract visiting hunters to Ethiopia [47]. However, over exploitation of wildlife resources negatively affects the population of many large animals and habitats, where tourists recreate.

\section{Conclusion}

The wildlife tourism industry of Ethiopia is mainly dependent on protected areas (national parks and sanctuaries). The country has rich in wildlife diversity; exclusively large mammals and attract many tourists locally and internationally. Nature based tourism offers high revenue away from agricultural production. The Ethiopia’s protected areas are expanding; currently more than 55 including national parks and sanctuaries. The three eco-region; montane and Afroalpine ecosystem, Great Rift Valley and southwestern transboundary ecosystem are best tourism destination in Ethiopia. Nature-based tourism which serves dual purposes; protects the various unique wildlife species and improving the livelihoods of local communities. However, protected areas and tourism destination sites are under severe threat. Failure to conserve protected areas will have dire consequences for biodi- 

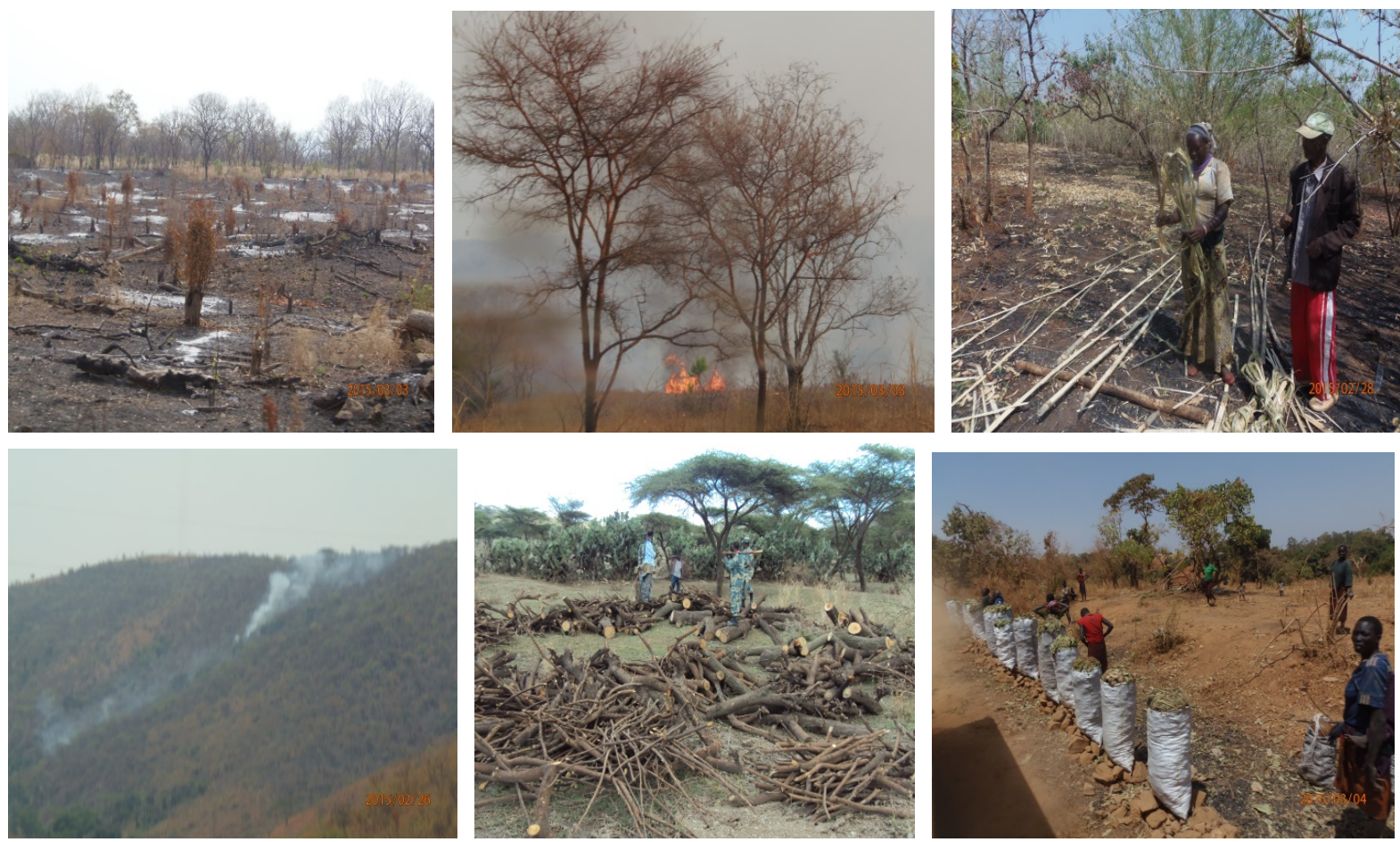

Figure 13. Deforestation practices (Photo by Alemneh Amare, 2015).
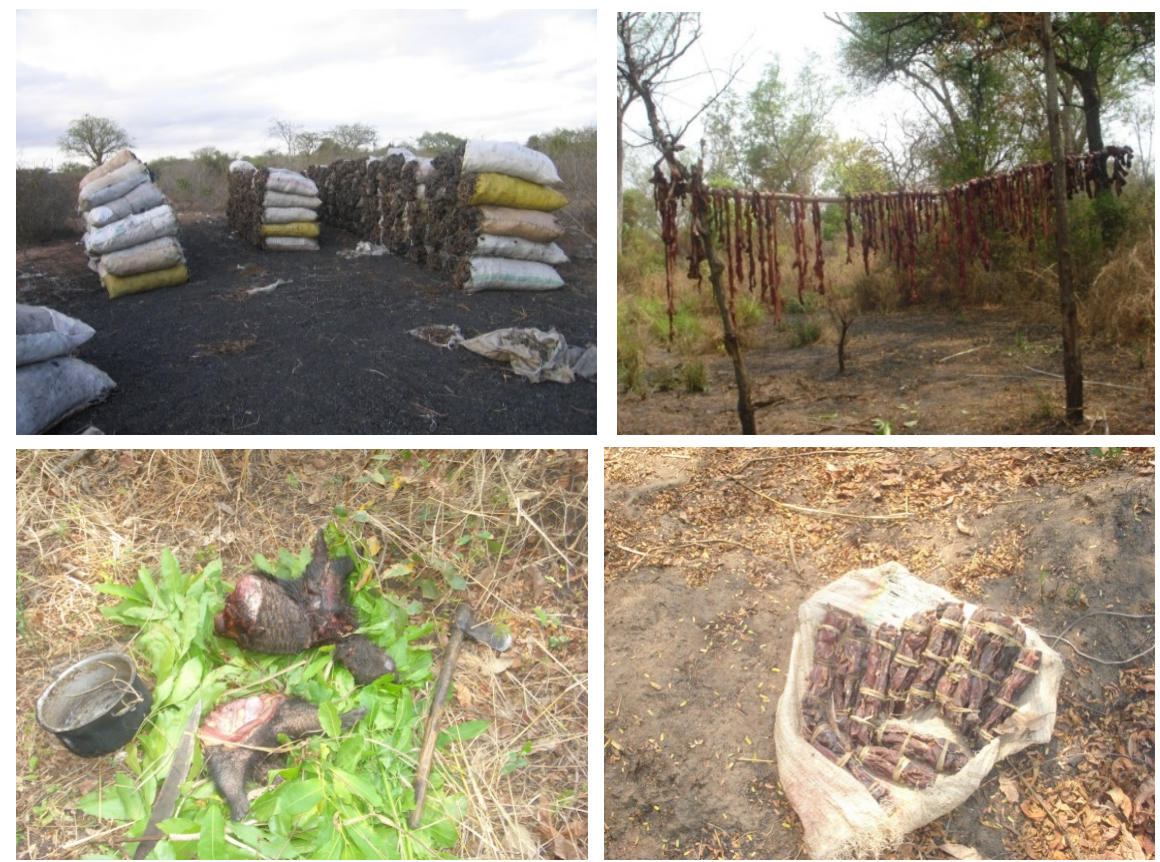

Figure 14. Some challenges of wildlife tourism and wildlife conservation.

versity conservation; will preclude the sustainable use of wildlife as a development option and have long term negative impacts on tourism industry in general.

\section{Future Direction for Nature-Based Tourism and Wildlife Conservation}

The wildlife conservation authorities have to; stress on to decrease the negative impacts on nature and culture 
which damage a tourism destination through education or teaching the importance of conservation benefits. Direct revenue from conservation and management of protected area, strive and maximize economic benefit for the host country and local communities, especially peoples living in and adjacent to protected areas. Further infrastructure expanding and the locals have to be benefited from the visitors.

\section{Acknowledgements}

I would like to thank for my family, Wolkite University especially department of Natural Resource Management staff members, and scholars who support and provide information for this manuscript and cooperation to be fruitful. I also thanks to the Ethiopian Wildlife Conservation Authority for providing different pictures and supporting this ideas.

\section{References}

[1] Sinha, C. (2001) Wildlife Tourism: A Geographical Perspective. Conference Paper, 1-23.

[2] Akama, J.S. (1999) The Evolution of Tourism in Kenya. Journal of Sustainable Tourism, 7, 6-25. http://dx.doi.org/10.1080/09669589908667324

[3] Nelson, F. (2009) Reforming Wildlife Governance in East and Southern Africa: The Role of Corruption. Working Paper, 7.

[4] Wolff, J.V. (1961) Wildlife in Ethiopia. Ethiopian Forestry Review, 2, 3-13.

[5] Irandu, M.E. (2004) The Role of Tourism in the Conservation of Cultural Heritage in Kenya. Asia Pacific Journal of Tourism Research, 9, 133-151. http://dx.doi.org/10.1080/1094166042000233658

[6] Shackley, M. (1996) Wildlife Tourism. International Thomson Business Press, London.

[7] Orams, M.B. (2002) Feeding Wildlife as a tourism Attraction: A Review of Issues and Impacts. Tourism Management, 23, 281-293. http://dx.doi.org/10.1016/S0261-5177(01)00080-2

[8] Tisdell, C. and Wilson, C. (2003) Economics of Wildlife Tourism. Working Paper, 88.

[9] Hendee, J. and Roggenbuck, J. (1984) Wilderness Related Education as a Factor Increasing Demand for Wilderness. Paper Presented at the International Forest Congress Convention, Quebec City.

[10] Young, J. (2012) Ethiopian Protected Areas: A “Snapshot”. Word Press, Addis Ababa, 23.

[11] EBI (2014) Ethiopia’s Fifth National Report to the Convention on Biological Diversity. Ethiopian Biodiversity Institute, Addis Ababa.

[12] Amare, A., Hernandez, A., Mekonnen, A., Hylander, K. and Hayward, M.W. (In Preparation) Human-Wildlife Conflict in and around Gibe Sheleko National Park, Southwestern Ethiopia.

[13] Bekele, A. and Yalden, D. (2013) The Mammals of Ethiopia and Eritrea. Addis Ababa University Press, Addis Ababa.

[14] Yalden, D. and Largen, M. (1992) Endemic Mammals of Ethiopia. Mammal Review, 22, 115-150. http://dx.doi.org/10.1111/j.1365-2907.1992.tb00128.x

[15] WCMC (1994) Biodiversity Data Sourcebook. World Conservation Monitoring Centre, World Conservation Press, Cambridge.

[16] Blower, J. (Undated) The Wildlife of Ethiopia. Oryx, 13, 276-283.

[17] Vreugdenhil, D., Vreugdenhil, A.M., Tilahun, T., Shimelis, A. and Tefera, Z. (2012) Gap Analysis of the Protected Areas System of Ethiopia, with Technical Contributions from Nagelkerke, L., Gedeon, K., Spawls, S., Yalden, D., Berhanu, L. and Siege, L. Ethiopian Wildlife Conservation Authority (EWCA), Addis Ababa.

[18] Tefera, M. (2011) Wildlife in Ethiopia: Endemic Large Mammals. Current Zoology, 6, 108-116.

[19] Amare, A. (2015) Conservation Challenges of Gibe Sheleko National Park, Southwestern Ethiopia. Natural Resources, 6, 286-289. http://dx.doi.org/10.4236/nr.2015.64025

[20] Dickinson, E.C. (2003) The Howard and Moore Complete Checklist of the Birds of the World. Revised and Enlarged 3rd Edition, Princeton University Press, Princeton.

[21] Fish Base. http://www.fishbase.org

[22] Living National Treasures: Ethiopia. http://ntreasures.com/ethiopia.html

[23] Reptile Database. http://www.reptile-database.org/

[24] Groves, C.P. (2005) Order Primates. In: Wilson, D.E. and Reeder, D.M., Eds., Mammal Species of the World: A Taxonomic and Geographic Reference, 3rd Edition, Johns Hopkins University Press, Baltimore, 111-184. 
[25] Kingdon, J., Gippoliti, S., Butynski, T.M., Lawes, M.J., Eeley, H., Lehn, C. and De Jong, Y. (2008) Cercopithecus mitis. In: IUCN 2010, IUCN Red List of Threatened Species. Version 2014.1. www.iucnredlist.org

[26] Bruche, S., Gusset. M., Lippold, S., Barnett, R., Eulenberger, K., Junhold, J., Driscoll, A.C. and Hofreiter, M. (2012) A Genetically Distinct Lion (Panthera leo) Population from Ethiopia. European Journal of Wildlife Research, 59, 215225. http://dx.doi.org/10.1007/s10344-012-0668-5

[27] Wolff, J.V. (1961) Wildlife in Ethiopia. Ethiopian Forestry Review, 2, 3-13.

[28] Zelalem, T. (2007) Community Attitudes towards Wildlife Conservation in Ethiopia. Proceedings of the 2007 George Wright Society Conference, 287-292.

[29] Murray, M. and Admasu, B. (2013) Development of a Marketing Strategy for Wildlife Tourism in Ethiopia. Unpublished Report, 65.

[30] Reddy, R.U. and Workeneh, S. (2014) Conflicts between the Conservation of Elephant and Human Activities: In the Case of Babile Elephant Sanctuary (BES), Ethiopia. European Academic Research, 2, 1280-1292.

[31] Tedla, S. (1995) Protected Areas Management Crisis in Ethiopia. Walia, 16, 17-30.

[32] Wilfred, P. (2010) Towards Sustainable Wildlife Management Areas in Tanzania. Tropical Conservation Science, 3, 103-116.

[33] Birdlife International (2001) Important Bird Areas in Africa and Associated Islands-Ethiopian Wild Life and Natural History Society. Unpublished Report, 32.

[34] Yihune, M., Bekele, B. and Tefera, Z. (2008) Human-Gelada Baboon Conflict in and around the Simien Mountains National Park, Ethiopia. African Journal of Ecology, 19, 1-7.

[35] Kumsa, T. (2006) Human-Wildlife Conflict and Population Status of Swayne’s Hartebeest (Alcelaphus buselaphusswaynei) in Senkele Swayne’s Hartebeest Sanctuary. Master's Thesis, Addis Ababa University, Addis Ababa.

[36] Wolde-Yohannes, D. (2006) Diversity, Distribution and Relative Abundance of the Avian Fauna of Chebera Churchura National Park, Ethiopia. Master's Thesis, Addis Ababa University, Addis Ababa.

[37] Admasu, M. (2006) History and Status of the Population of African Elephant (Loxodonta africana Blumbenbach, 1979) and Human-Elephant Conflict in Chebera Churchura National Park, Ethiopia. Master's Thesis, Addis Ababa University, Addis Ababa.

[38] EWNHS, Ethiopian Wildlife Natural History Museum Society (2001) Important Bird Areas in Ethiopia. Review Paper, 291-336.

[39] African Development Bank (2014) African Economic Outlook. Unpublished Report, 58.

[40] Ondicho, T.G. (2000) International Tourism in Kenya: Development, Problems and Challenges. EASSRR, 9, 49-69.

[41] Magige, F.J. (2012) Human-Wildlife Interaction in Serengeti and Ngorongoro Districts of Tanzania: A Case Study on Small Mammals. Tanzania Journal of Science, 38, 95-105.

[42] Messana, G.M. and Bereket, N. (1994) The Senkele Swayne’s Hartebeest Sanctuary Management Plan. Ethiopian Wildlife Conservation Department, Addis Ababa.

[43] Bishaw, B. (2001) Deforestation and Land Degradation in Ethiopian High Lands: A Strategy for Physical Recovery. North East African Studies, 8, 7-25. http://dx.doi.org/10.1353/nas.2005.0014

[44] Masanja, G.F. (2014) Human Population Growth and Wildlife in Ugalla Ecosystem, Western Tanzania. Journal of Sustainable Development Studies, 2, 192-217.

[45] Meduna, A.J., Ogunjinmi, A.A. and Onadeko, S.A. (2009) Biodiversity Conservation Problems and Their Implications on Ecotourism in Kainji Lake National Park, Nigeria. Journal of Sustainable Development in Africa, 10, 59-73.

[46] Stuart, S.N., Adams, R.J. and Jenkins, M.D. (1990) Biodiversity in Sub-Saharan Africa and Its Islands: Conservation, Management, and Sustainable Use. Occasional Paper of the IUCN Species Survival Commission, 86.

[47] Lindsey, P.A. (2008) Trophy Hunting in Sub-Saharan Africa: Economic Scale and Conservation Significance. In: Baldus, R.D., Damm, G.R. and Wollscheid, K., Eds., Best Practices in Sustainable Hunting, 41-47. 